ABDIMAS: Jurnal Pengabdian Masyarakat Universitas Merdeka Malang
Vol.6(3) August 2021, 347-357
p-ISSN: 2721-138X e-ISSN: $2548-7159$
http://jurnal.unmer.ac.id/index.php/jpkm

\title{
Pengembangan Industri UMKM Batik Khas Kabupaten Malang melalui Digitalisasi Marketing Mix dan Teknologi
}

\author{
Vika Annisa Qurrata1, Ermita Yusida', Sudjatmiko Sudjatmiko², Lustina Fajar Prastiwi \\ 'Departemen Ekonomi Pembangunan, Fakultas Ekonomi, Universitas Negeri Malang \\ $J$. Semarang No.5, Malang, 65145, Indonesia \\ ${ }^{2}$ Departemen Teknik Mesin, Fakultas Teknik, Universitas Merdeka Malang \\ Jl. Terusan Raya Dieng No.62-64 Malang, 65146, Indonesia
}

\begin{abstract}
ARTICLE INFO
Received: 2020-11-02

Revised: 2021-02-26

Accepted: 2021-05-07

Keywords:

Appropriate technology, Batik,

Digital marketing mix, Increased productivity, Market engagement, Small and mediumsized enterprises (SMES)

\section{ABSTRACT}

The development of SMEs is still one of the development priorities in Indonesia. One example is the Dewandaru Batik industry in Malang Regency. The business, which was started in 2017 and is engaged in batik cloth production, carries out the production process manually with limited tools. The price that is determined tends to be very cheap compared to batik marketed through the market and online galleries. Moreover, every month's limited production is the impact of the lack of technology used and little marketing. Marketing and utilization of appropriate technology are still the main obstacles faced; therefore, the solution to this problem is digitizing the marketing mix and proper technology. The method used is identifying problem-solving and assistance for increasing industrial innovation and digital marketing. The result of this activity was an increase in Dewandaru's batik industry's productivity with the help of a batik stamp tool and a dipping tub used for the coloring process. Furthermore, increasing quality makes for a broader marketing market. Batik Dewandaru also experienced improvements in business management because it made simple financial reports on the results of business management training.
\end{abstract}

(C)2021 Published by University of Merdeka Malang. This is an open access article distributed under the CC BY-SA 4.0 license

(https://creativecommons.org/licenses/by-sa/4.0/)

How to cite: Qurrata, V. A., Yusida, E., Sudjatmiko, S., \& Prastiwi, L. F. (2021). Pengembangan Industri UMKM Batik Khas Kabupaten Malang melalui Digitalisasi Marketing Mix dan Teknologi. Abdimas: Jurnal Pengabdian Masyarakat Universitas Merdeka Malang, 6(3), 347-357. https://doi.org/10.26905/abdimas.v6i3.4978

\section{PENDAHULUAN}

Batik merupakan kerajinan tradisional khas Indonesia yang diaplikasikan dalam berbagai media, salah satunya adalah kain. Kain batik pada akhirnya menjadi salah satu trade-mark berbusana formal dan informal penduduk Indonesia dan menjadi suatu potensi industri. Besarnya kebutuhan kain batik menjadikan produksi kain batik menjadi sangat potensial dalam memenuhi kebutuhan sandang. Menilik catatan Kementerian Peridustrian (Kemenperin, 2016), mencatat bahwa nilai total ekspor atas produksi batik mencapai USD 149,9 juta dengan pasar utamanya Jepang, Amerika Serikat, dan Eropa. Selain itu, industri batik ini juga merupakan industri padat karya yang menyerap banyak tenaga kerja. Usaha Mikro 
ABDIMAS: Jurnal Pengabdian Masyarakat Universitas Merdeka Malang Volume 6, No. 3, August 2021: 347-357

Kecil dan Menengah merupakan suatu usaha yang berperan penting dalam perekonomian nasional. Pada saat ini UMKM gencar dijalankan di berbagai daerah di Indonesia. Dalam Mandasari (2019), tercatat bahwa pelaku usaha batik di Indonesia didominasi oleh Industri Kecil dan Menengah (IKM) yang tersebar di 101 sentra. Jumlah tenaga kerja yang terserap di sentra IKM batik pun mencapai 15 ribu orang. Berdasarkan data tersebut, industri batik berperan penting untuk peningkatan perekonomian nasional melalui peningkatan jumlah wirausaha, penyedia lapangan kerja dalam mengentaskan problematika pengangguran, dan penyumbang devisa negara melalui ekspor yang dilakukan atas produk tersebut. Untuk itu, pelestarian dan perkembangan industri batik yang menghasilkan kualitas dan ciri khas daerah harus mendapat dukungan dari semua pihak baik dari pemerintah hingga masyarakat luas (Ulum, 2009).

Pada kenyataan bahwa batik dapat menjadi salah satu penopang perekonomian negara ternyata tidak menjadikan industri batik menjadi industri yang menarik minat masyarakat. Kemenperin menyatakan dalam berita industri, bahwa berdasarkan data Badan Pusat Statistik (BPS) Indonesia mengimpor kain dan produk jadi batik dari Tiongkok sebanyak 1.037 ton bernilai USD 30 juta atau sekitar Rp285 miliar. Sebagian besar adalah batik printing (cetakan mesin). Primadhyta (2015) memberitakan bahwa BPS pada tahun 2013 mencatat Indonesia mengimpor sebanyak 282,3 ton produk batik dari berbagai negara dengan nilai mencapai USD 5,2 miliar pada tahun 2013. Impor terbesar berasal Tiongkok sebesar 136,8 ton, senilai USD 2,1 juta. Setelah itu disusul oleh Italia yang mengirim produk batiknya ke tanah air sebesar 43,1 ton, senilai USD 937,6 ribu. Negara lain yang mengekspor produk batiknya ke Indonesia adalah Hongkong, Korea Selatan, dan Jepang. Kondisi ini memaksa industri batik Indonesia untuk dapat bersaing dengan produk batik impor. Fakta tersebut cukup mengejutkan karena sebagai pemilik hak paten batik yang telah diberikan oleh UNESCO kepada Indonesia, tidak menjadikan Indonesia sebagai negara yang independen dalam peningkatan produksi batik dalam negeri. Kelemahan dalam pengelolaan produk lokal merupakan akibat daya saing yang sangat lemah serta produk tidak mampu berkompetisi dengan produk impor (Nugrayasa, 2014)

Fakta kegiatan impor batik cap yang dilakukan oleh pemerintah menunjukkan bahwa pengrajin dalam negeri belum mampu memenuhi stok kebutuhan batik dalam negeri (Alhusain, 2015). Padahal Indonesia sendiri merupakan pasar yang besar dan potensial bagi pemasaran produk lokal yang mampu meningkatkan keefektifan perekonomian dalam negeri melalui sentra industri kecil dan menengah khususnya industri batik. Indonesia sendiri sebenarnya telah memiliki 25 daerah penghasil batik dengan ciri khasnya masing-masing. Wujud visual motif batik menjadi salah satu pembeda karakter dan dari mana asal batik tersebut diproduksi (Kurniawati, 2017). Misalkan pada motif Batik Solo, Batik Jogja, Batik Cirebon, Batik Jepara, Batik Aceh, Batik Betawi, dan tak terkecuali Batik Malang.

Malang adalah suatu daerah di Jawa Timur memiliki 2 wilayah administrasi yaitu Kota Malang dan Kabupaten Malang. Kota Malang terdiri dari 4 kecamatan dan Kabupaten Malang terdiri atas 33 kecamatan. Malang adalah salah satu kota pelajar terbesar dan memiliki daya kreativitas yang sangat baik dalam pengembangan potensi daerah. Salah satu potensi yang cukup berkembang adalah batik. Terdapat setidaknya 10 motif batik khas Malang diantaranya Batik Tugu, Batik Teratai, Batik Rumbai Singa, Batik Singosari, Batik Sulur-Sulur, dan lain sebagainya (Latief, 2019). Berbagai corak ini dihasilkan dari hasil kreativitas dan filosofis Malang berdasarkan sejarah dan keunggulan daerah yang dimilikinya. 


\section{Pengembangan Industri UMKM Batik Khas Kabupaten Malang melalui Digitalisasi Marketing Mix dan Teknologi}

Vika Annisa Qurrata, Ermita Yusida, Sudjatmiko Sudjatmiko, Lustina Fajar Prastiwi

Dalam konteks inilah, batik bukan sekedar budaya khas Indonesia, tetapi kekayaan intelektual Bangsa Indonesia dan nafas serta penggerak kehidupan sebagian masyarakat Indonesia (Ulum, 2009).

Sejauh ini, Kabupaten Malang telah memiliki komunitas pengajin batik yang dinaungi langsung oleh Dinas Perdagangan dan Perindustrian (Disperindag) dalam peningkatan kemampuan membatik dan pemasaran. Setidaknya, terdapat 30 kelompok pengajin batik dengan skala usaha mikro dan kecil yang tersebar di berbagai kecamatan di Kabupaten Malang. Pelaku usaha merupakan rumah tangga minim modal dalam menjalankan usahanya namun terdapat kreativitas dan kemauan yang sangat baik dalam tiap pelaku usaha. Dalam konteks ini berkorelasi dengan Bourdieu (2009), modal berperan sebagai sebuah relasi sosial yang terdapat di dalam suatu sistem pertukaran, yang diperluas pada segala bentuk barang baik materiil maupun simbolis. Hal ini membuat jumlah produksi yang mereka lakukan sangat terbatas karena alat dan pegawai yang mereka miliki masih cukup minim. Minimnya jumlah alat membatik dan keterbatasan modal yang dimiliki pengrajin menjadi suatu halangan yang cukup mengganjal bagi kemajuan pengrajin batik dan produksi yang dilakukan. Tidak terkecuali dengan UMKM Batik Tulis Dewandaru yang beralamat di Dusun Kampung Baru, Kecamatan Wonosari, Kabupaten Malang.

UMKM Batik Tulis Dewandaru ini berdiri pada tahun 2017 dan bergerak di bidang produksi kain batik tulis khas Kabupaten Malang, Jawa Timur. Bermula dari ketertarikan seorang ibu rumah tangga bernama Suharnik akan pembuatan batik, maka produksi batik ini mulai digagas dan diproduksi. Proses produksi dilakukan secara manual dengan alat dan bahan yang terbatas. Usaha yang telah berjalan selama 2 tahun ini sudah mampu menarik minat warga sekitar. Hingga kini, produksi kain batik tulis yang dihasilkan adalah 10 buah per bulan dengan harga rata-rata Rp250.000-Rp1.000.000 per lembar kain batik. Kisaran harga yang ditentukan cenderung sangat murah bila dibandingkan dengan harga batik yang telah dipasarkan melalui pasar online maupun galeri. Selain itu, terbatasnya produksi yang dilakukan tiap bulannya merupakan dampak masih minimnya modal yang digunakan dan pemasaran yang terbatas.

Berdasarkan tinjuan penulis, permasalahan pertama yang dihadapi oleh UMKM Batik Tulis Dewandaru adalah tidak adanya peralatan untuk membatik secara modern seperti canting listrik, media pewarnaan batik yang canggih, stamp cap, dan kompor listrik yang memadai. Permasalahan kedua adalah tidak adanya rantai pemasaran yang berkelanjutan walaupun mereka merupakan UKM binaan Dinas Koperasi Kabupaten Malang, namun mereka masih harus mencari konsumen secara mandiri dengan cara mengikuti pameran atau pemasaran dari mulut ke mulut. Keterbatasan ini mengakibatkan jumlah produksi terbatas serta masih sedikitnya jumlah pemesanan yang berdampak pada penjualan kain batik yang tidak signifikan.

Gambar 1 merupakan alat-alat yang digunakan oleh pembatik selama ini. Canting yang digunakan merupakan canting tradisional yang belum menggunakan listrik. Selain itu, dalam proses membuat pola batik, pembatik juga menggunakan kertas serta sketsa manual. Belum menggunakan pola stamp sehingga untuk pengerjaan satu kain batik saja membutuhkan waktu sekitar 1 bulan mulai dari desain hingga batik siap dijual pada konsumen.

Berdasarkan kondisi mitra, maka program pengabdian masyarakat ini bertujuan untuk memberikan solusi pada permasalahan yang dihadapi oleh mitra. Solusi yang ditawarkan berupa pemberian 
ABDIMAS: Jurnal Pengabdian Masyarakat Universitas Merdeka Malang Volume 6, No. 3, August 2021: 347-357

peralatan yang tepat guna untuk meningkatkan kualitas dan kuantitas produksi, peningkatan penjualan melalui pemasaran digital serta perbaikan manajemen usaha melalui pelatihan pencatatan keuangan sederhana.
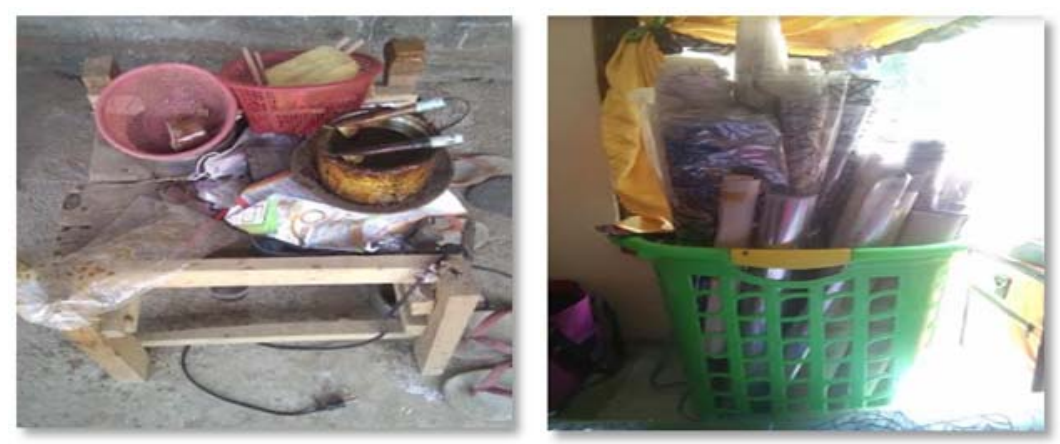

Gambar 1. Kondisi alat yang digunakan dalam membatik berupa canting manual dan membuat desain batik berupa sketsa di kertas

\section{METODE}

Pelatihan ini dilakukan di Dusun Baru, Kecamatan Wonosari, Kabupaten Malang. Mitra yang terlibat dalam pelatihan ini yaitu kelompok UMKM Batik Dewandaru, Kabupaten Malang. Berdasarkan hasil pra-survei, ditemukan beberapa permasalahan yang dihadapi oleh kelompok UMKM ini. Beberapa permasalahan yang dihadapi yaitu minimnya teknologi yang digunakan dan terbatasnya pemasaran. Untuk menyelesaikan permasalahan yang dihadapi oleh Batik Dewandaru, maka tim merumuskan metode penyelesaian yang tepat bagi mitra. Metode yang digunakan dalam kegiatan pengabdian kepada masyarakat ini terdiri dari 3 fase, yaitu: (1) Identifikasi dan pemecahan masalah. Berdasarkan identifikasi masalah terdapat 3 masalah utama dalam pengembangan industri Batik Dewandaru yaitu terbatasnya sarana dan prasarana untuk menunjang inovasi, rendahnya kemampuan dalam pemasaran yang digunakan serta terbatasnya jaringan pemasaran yang mitra miliki, dan belum maksimalnya manajemen tata usaha yang dilakukan. Dari ketiga identifikasi permasalahan tersebut, secara lebih rinci solusi yang diberikan oleh tim pengabdian terdapat 3 solusi, yaitu (a) Memberikan bantuan sarana peningkatan inovasi industri berupa penyediaan perlengkapan proses membatik berbasis IPTEK yaitu dengan bantuan bak celup pewarnaan. Selain itu juga memberikan peralatan membatik secara modern seperti alat batik cap, canting elektrik, dan kompor listrik; (b) Memberikan pelatihan penggunaan konten yang strategis melalui digital marketing mix; (c) Pelatihan manajemen usaha serta pengenalan financial technology untuk meningkatkan daya saing UMKM; (2) Pelaksanaan kegiatan. Pada fase ini tim pengabdian melakukan kunjungan dan pendampingan serta melakukan kerjasama untuk melaksanakan rencana pemecahan solusi pengembangan Batik Dewandaru; (3) Evaluasi. Kegiatan evaluasi ini dilakukan untuk melihat apakah bantuan berupa sarana serta pelatihan dan pendampingan usaha berjalan lancar atau tidak. Selain itu juga untuk melakukan evaluasi pencapaian setelah diadakan kegiatan bagaimana hasil dan dampaknya terhadap pengembangan Batik Dewandaru. 


\section{HASIL DAN PEMBAHASAN}

\section{Peningkatan inovasi industri Batik Tulis Dewandaru}

Inovasi merupakan salah satu strategi utama di era Industri 4.0 ini. Dimana inovasi merupakan ide, praktik, atau objek yang dianggap baru oleh individu atau unit lain dari adaptasi (Hoti, 2015). Inovasi di era digital ini menjadi titik sentral dan dipercaya sebagai kunci dari peningkatan produktivitas suatu usaha (Setyorini \& Susilowati, 2019; Nugrayasa, 2014). Namun nyatanya, inovasi ini tidak banyak dilakukan oleh UMKM di Indonesia, begitu juga di industri Batik Tulis Dewandaru. Hal ini terjadi karena biaya inovasi cukup mahal untuk sekelas UMKM (Ulliyawatik, 2018). Karakteristik UMKM yang hanya cukup untuk produksi saja, membuat industri kecil ini kesulitan untuk mengembangkan inovasi. Oleh karena itu, tim pelaksana hadir sebagai pencerah dan mewujudkan inovasi untuk dapat diadaptasi oleh industri Batik Tulis Dewandaru.

Inovasi yang dilakukan oleh tim pelaksana untuk industri Batik Tulis Dewandaru yaitu berupa desain sarana prasarana yang tepat guna. Tidak berhenti pada desain, namun tim pelaksana juga membuat teknologi tepat guna tersebut untuk menunjang produksi Batik Dewandaru agar produktivitasnya meningkat. Terdapat 2 (dua) kegiatan utama dalam pengembangan inovasi ini.

\section{Penyediaan perlengkapan proses membatik berbasis IPTEK}

Pertama yang dilakukan tim pelaksana kegiatan yaitu melakukan koordinasi dengan ketua industri Batik Dewandaru mengenai alat dan bahan yang digunakan dalam pembuatan batik. Selain itu juga proses pembuatan yang selama ini dilakukan. Dari koordinasi ini maka tim pelaksana melakukan identifikasi prioritas inovasi yang dapat dijalankan. Secara lebih jelas proses koordinasi dapat dilihat pada Gambar 2.
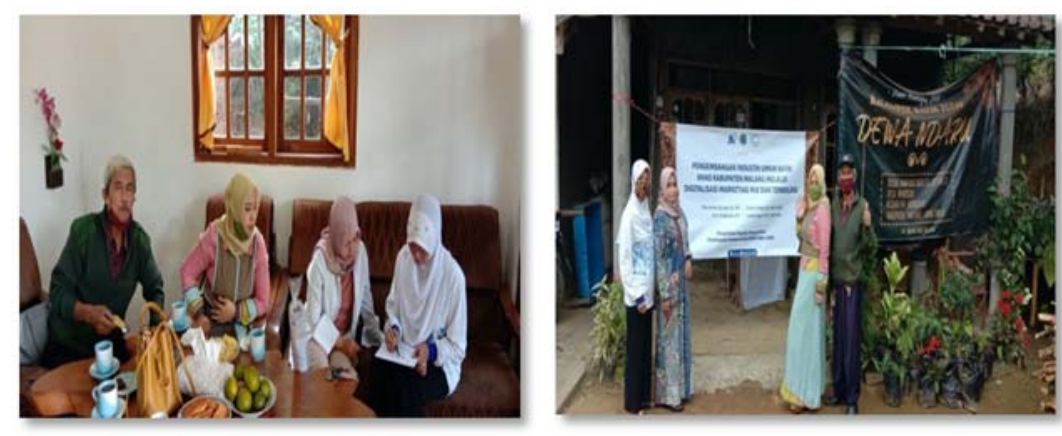

Gambar 2. Koordinasi pembahasan alat dan bahan serta proses pembuatan batik Gambar 3. Kegiatan koordinasi di tempat produksi Batik Dewandaru

Berdasarkan kegiatan koordinasi yang ditunjukkan pada Gambar 2 dan 3 telah dihasilkan kesimpulan inovasi yang akan dibantu oleh tim pelaksana. Selain itu terdapat beberapa bahan lain yang lebih modern seperti alat canting dan juga peningkatan produktivitas dengan membuat batik cap. Untuk itu masih diperlukan koordinasi lagi karena Batik Dewandaru harus membuat desain batik cap terlebih dahulu. 
ABDIMAS: Jurnal Pengabdian Masyarakat Universitas Merdeka Malang Volume 6, No. 3, August 2021: 347-357

Industri Batik Tulis Dewandaru selama ini masih menggunakan perlengkapan manual untuk proses mambuat kain batiknya. Seperti misalnya alat pewarna kain hanya memakai bak yang prosesnya tentu memakan waktu yang lama. Untuk itu tim pelaksana kegiatan membuatkan bak celup batik putar menggunakan fiber. Bak celup batik berbahan fiber ini memiliki beberapa kelebihan yaitu awet serta warna produk yang dihasilkan bisa menjadi lebih rata selain itu meminimalisir waktu produksi. Secara lebih jelas bak celup ini dapat dilihat pada Gambar 4.
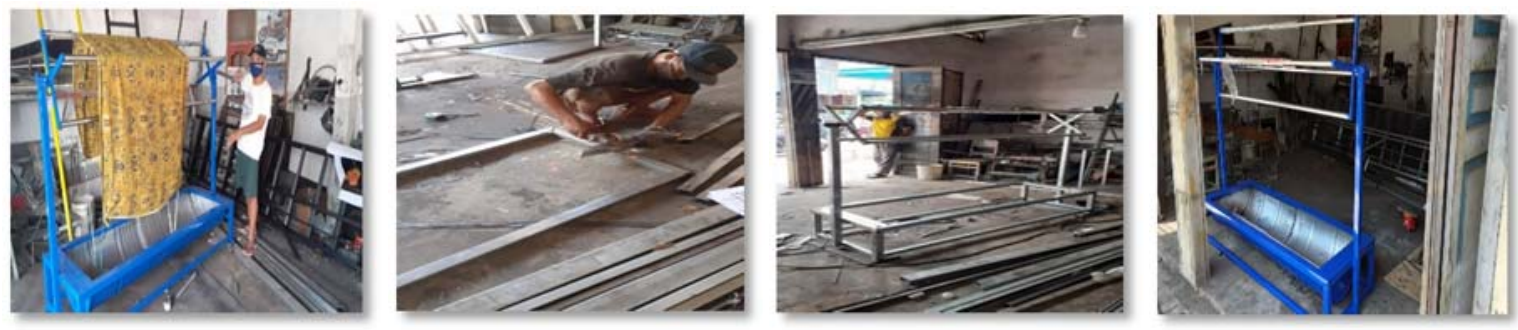

Gambar 4. Bak celup pewarna batik

Gambar 5. Pengelasan bak celup

Gambar 6. Bak celup pewarnaan

Pembuatan bak celup ini di desain khusus oleh Dr. Ir. Sudjatmiko, M. T. yang merupakan spesialis pada teknik mesin. Proses pembuatan diawasi secara khusus oleh tim pelaksana agar bak celup yang dihasilkan sesuai dengan desain yang diminta. Secara lebih jelas proses pembuatan bak celup ini dapat dilihat pada Gambar 5-6. Alat bak celup pewarna ini sudah diberikan kepada industri Batik Dewandaru untuk mempercepat proses produksi. Hal ini sangat efektif jika dibandingkan cara manual yang sebelumnya dilakukan dengan menggunakan bak plastik kecil-kecil.

\section{Pemberian peralatan membatik secara modern}

Berdasarkan koordinasi 1 yang sudah dijelaskan sebelumnya, peralatan-peralatan membatik secara modern seperti canting listrik, stamp cap, dan kompor elektronik diperlukan untuk hasil produksi yang lebih maksimal. Spesifikasi peralatan yang akan diberikan adalah semua canting dan kompor menggunakan listrik serta stamp cap untuk batik cap dengan ukuran $18 \times 18 \mathrm{~cm}$ dan $16 \times 16 \mathrm{~cm}$. Secara lebih jelas, peralatan tersebut dapat dilihat pada Gambar 7-9.
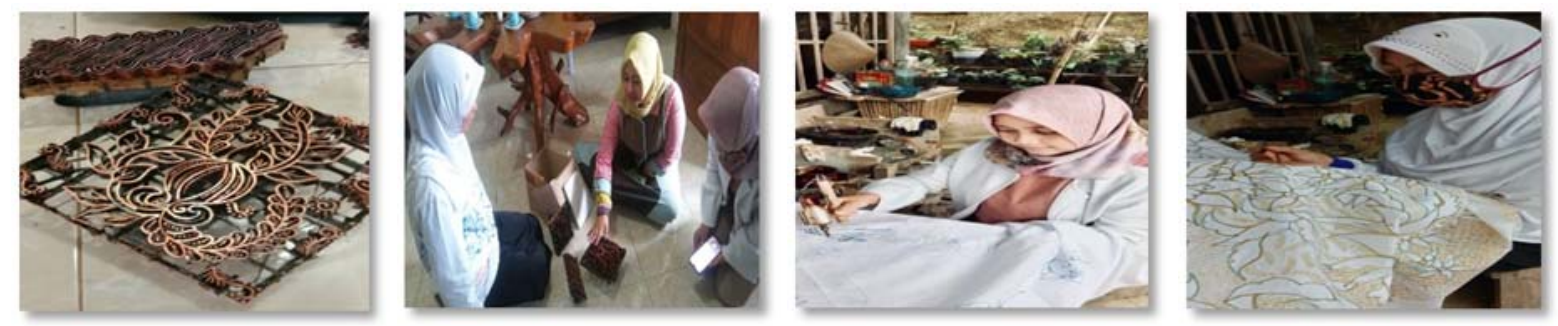

Gambar 7. Alat batik cap sesuai desain Batik Dewandaru

Gambar 8. Penyerahan dan arahan penggunaan alat batik cap

Gambar 9. Penggunaan canting listrik 
Canting listrik membuat proses pembatikan menjadi lebih rapi dan cepat. Hal ini dikarenakan panas yang dihasilkan stabil. Berbeda jika menggunakan canting manual yang terkadang ketika dibutuhkan apinya ati dan dingin. Tentunya ini akan menghambat produksi. Selain itu, batik cap akan lebih banyak diproduksi karena batik cap ini banyak diminati masyarakat dan harganya yang sangat terjangkau. Hal ini juga akan menambah daya saing dari industri Batik Dewandaru.

\section{Pelatihan penggunaan konten yang strategis (market engagement) melalui digital marketing mix}

Dalam era industri 4.0 dan era digital, UMKM tidak hanya dituntut pandai dalam produksi namun juga pandai dalam melakukan pemasaran baik secara konvensioal ataupun online (Rahmiaji et al., 2020). Konsep digital marketing mix menjadi strategi dalam pemasaran Batik Dewandaru yang diberikan oleh tim pelaksana. Disini, kami menekankan pentingnya penggunaan digital marketing karena jangkauannya yang lebih luas, tersegmentasi, serta biaya yang cenderung lebih murah (Saveria, 2016) Sebelum dilakukan pelatihan maka tim pelaksana juga mendaftarkan Batik Dewandaru pada Google My Business. Hal ini dilakukan untuk menjaring engagement konsumen dan menandai bahkan ada batik tulis lokal yang berkualitas. Secara lebih jelas halaman utama Google My Business yang didaftarkan dapat dilihat pada Gambar 10.

Pembuatan akun Google My Business ini penting dikarenakan saat ini 70\% pelanggan potensial mencari bisnis secara online sebelum membuat keputusan pembelian atau sebelum mengunjungi. Pelanggan biasanya cenderung mencari informasi spesifik seperti acara, spesialisasi, penawaran, diskon, dan membandingkan berbagai bisnis berdasarkan produk/layanan mereka (Pradiani, 2017). Sehingga dari sini Batik Dewandaru dapat membuat postingan yang menonjol dengan berbagi foto terbaru, penawaran, dan informasi terkait lainnya melalui postingan tersebut dan pada akhirnya akan memperbanyak pelanggan.

Selain itu, media sosial seperti Instagram dan Facebook juga merupakan sarana jitu untuk memperluas pemasaran. Pemilihan media sosial ini disesuaikan dengan jenis produk industri yang sesuai. Kenyataanya tidak semua produk efektif menggunakan media sosial atau market place yang ada. Pada pelatihan ini, pemateri membantu Batik Dewandaru untuk membuat serta mengoperasikan media sosial sehingga mitra akan lebih mudah menggunakannya. Secara lebih rinci, akun Instagram dan Facebook batik Dewandaru yang telah dirancang oleh pemateri serta tim dapat dilihat pada Gambar 11-12.
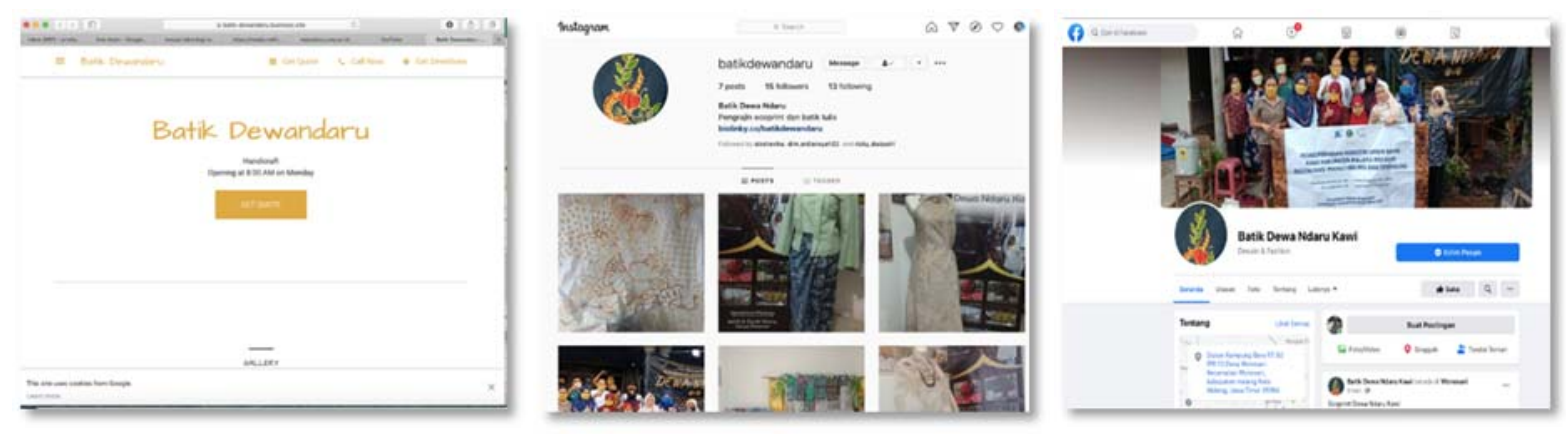

Gambar 10. Halaman pada Google My Business

Gambar 11. Halaman Instagram Batik Dewandaru Gambar 12. Halaman Facebook Batik Dewandaru 
ABDIMAS: Jurnal Pengabdian Masyarakat Universitas Merdeka Malang Volume 6, No. 3, August 2021: 347-357

Pelatihan Market Engagement melalui digital marketing mix ini diisi langsung oleh Putra Ramadhani, S.E., M.M. selaku praktisi dalam bidang manajemen pemasaran. Pada sesi ini Bapak Putra menjelaskan mengenai market engagement pada 15 orang peserta. Dalam sesi ini, dijelaskan strategi kegiatan komunikasi pemasaran Batik Dewandaru agar efektif dalam meningkatkan awareness dan minat terhadap Batik Dewandaru. Marketing mix sendiri memiliki 4 variabel yaitu produk, price (harga), promosi, place (tempat). Akan tetapi untuk memunculkan Market engagement, marketing mix harus ditambah beberapa variabel yaitu people (manusia), process, packaging, personel interest, public commentary melalui media sosial, personalization, dan predictive model atau kerap dikenal dengan istilah manajemen 7P (Kotler, 1991).

Pola marketing yang digunakan ini merupakan gabungan antara marketing online dan offline yang mana dilakukan karena tidak mendukungnya sinyal yang tersedia di lokasi UKM. Akan tetapi, marketing secara online melalui social media marketing Instagram juga tidak dilupakan karena bisa memudahkan calon pembeli dalam mencari penjual. Keuntungan menggunakan social media marketing Instagram sebagai media pemasaran adalah gratis, memiliki banyak pengguna, memungkinkan untuk memasukkan contact person, mudah, dan dapat terkoneksi dengan media sosial lainnya. Gambar 13 merupakan kegiatan pelatihan materi yang diisi oleh Bapak Putra Ramadhani, S.E., M.M.
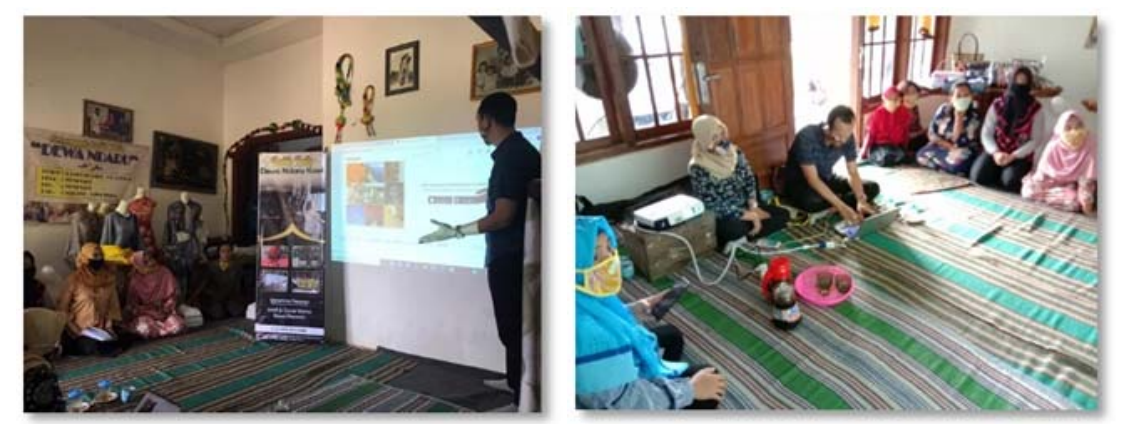

Gambar 13. Pelatihan market engagement melalui digital marketing mix yang dijelaskan oleh Putra Ramadhani, S.E., M.M

\section{Pelatihan manajemen usaha serta pengenalan financial technology untuk meningkatkan daya saing UMKM.}

Pada umumnya, UMKM kurang menerapkan manajemen dalam usahanya karena semua hal masih dikerjakan sendiri. Mulai dari aspek produksi, pemasaran, sumber daya manusia (SDM) hingga masalah manajemen keuangan. Manajemen usaha yang perlu diperbaiki oleh UMKM salah satunya adalah pelatihan perbaikan pola administrasi, pengembangan kreativitas, pengenalan financial technology, dan penguatan fokus bisnis.

Selain itu, pencatatan keuangan juga merupakan faktor penting dalam manajemen usaha. Dimana Batik Dewandaru ini belum memiliki pencatatan mengenai pengeluaran secara rinci dan lengkap, namun sudah ada pencatatan mengenai pemasukan dari sisi penjualan. Sehingga tim pengabdian memberikan pelatihan manajemen usaha. Pelatihan yang diikuti oleh 15 orang peserta memberikan gambaran pada 
sisi pelaporan keuangan dan juga pengetahuan mengenai financial technology sebagai upaya untuk memudahkan dalam melakukan transaksi jual beli Batik Dewandaru. Secara lebih rinci Gambar pelatihan menajemen usaha serta pengenalan financial technology dapat dilihat pada Gambar 14-16.
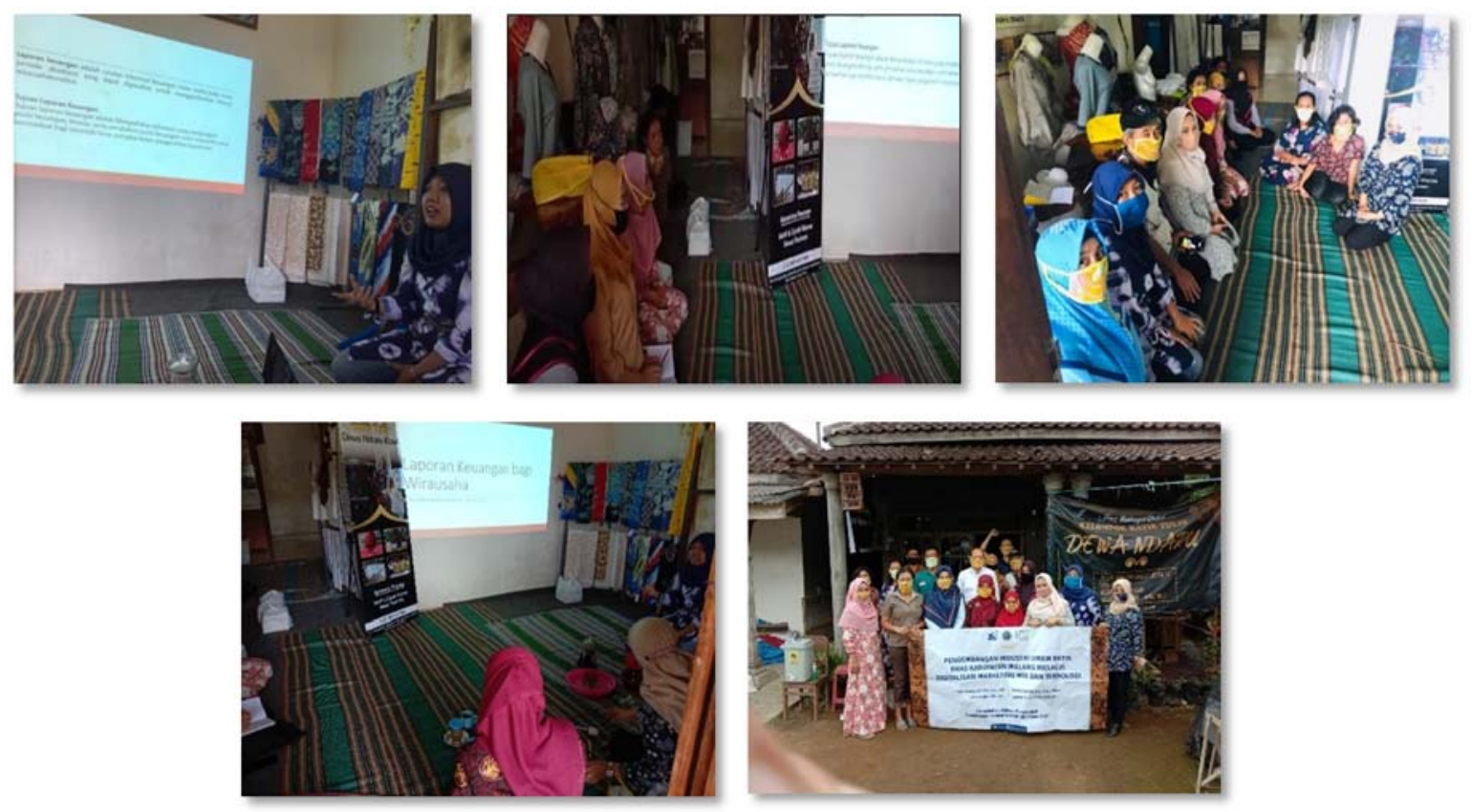

Gambar 14. Pemateri dan peserta pada Pelatihan Manajemen Usaha Serta Pengenalan Financial Technology Gambar 15. Peserta pelatihan melakukan Pelatihan Manajemen Usaha Serta Pengenalan Financial Technology Gambar 16. Foto bersama Bapak Camat Wonosari

Kegiatan Pengembangan Industri UMKM Batik Khas Kabupaten Malang melalui Digitalisasi Marketing Mix dan Teknologi juga mendapat dukungan dari pemerintah setempat. Bapak Camat Wonosari Kabupaten Malang serta kepala desa Kampung Baru juga turut hadir dalam acara pelatihan dan pendampingan industri batik Dewandaru.

Materi yang disampaikan dalam pelatihan ini yaitu meliputi macam-macam financial technology yang berkembang saat ini serta pembuatan dan pencatatan laporan keuangan secara sederhana. Tim pelaksana juga membuatkan master excel keuangan agar bisa digunakan langsung oleh Batik Dewandaru.

\section{Evaluasi hasil kegiatan}

Berdasarkan dari kegiatan yang sudah dilakukan, hasil evaluasi yang dapat diidentifikasi yaitu: (1) Produktivitas batik Dewandaru meningkat sebesar 20 persen. Dalam satu bulan penjualan Batik Dewandaru meningkat sebanyak 10 kain batik, hal ini tentunya juga mendorong Batik Dewandaru untuk melakukan produksi secara terus menerus; (2) Semakin dikenalnya Batik Dewandaru membuat produk unggulan batik ecoprint menjadi lebih banyak diminati. Minat masyarakat berdasarkan pemesanan 
ABDIMAS: Jurnal Pengabdian Masyarakat Universitas Merdeka Malang Volume 6, No. 3, August 2021: 347-357

meningkat sebanyak 60 persen; (3) Meningkatnya jaringan pemasaran melalui media sosial (Instagram, Facebook, dan My Google Business) yang ditandai dengan meningkatnya pemebelian dan pemesanan Batik Dewandaru; (4) Masih adanya kendala sarana berupa mesin fiksasi yang masih belum dimiliki Batik Dewandaru, terutama untuk proses pembuatan ecoprint.

\section{SIMPULAN DAN SARAN}

Berdasarkan penjelasan di atas, tujuan dari program ini yaitu untuk memberikan solusi pada permasalahan yang dihadapi oleh mitra. Solusi yang ditawarkan berupa pemberian peralatan yang tepat guna untuk meningkatkan kualitas dan kuantitas produksi, peningkatan penjualan melalui pemasaran digital serta perbaikan manajemen usaha melalui pelatihan pencatatan keuangan sederhana. Hasil dari solusi yang telah dilaksanakan adalah peningkatan tingkat produktivitas sebesar 20 persen, lebih dikenalnya Barik Dewandaru oleh masyarakat luas sehingga pemesanan meningkat sebanyak 60 persen, dan meningkatnya jaringan pemasaran melalui media sosial serta penguatan manajemen usaha mitra.

Meskipun program pengabdian yang telah dilakukan mendapatkan hasil yang memuaskan akan tetapi masih terdapat sejumlah keterbatasan, yaitu belum adanya mesin untuk fiksasi kain batik sebelum diwarnai serta konsistensi mitra dalam mengunakan media sosial untuk marketing. Berdasarkan keterbatasan diatas, maka saran yang dapat dilakukan pada pengabdian selanjutnya yaitu: (1) Masih diperlukan penerapan IPTEK untuk mesin fiksasi agar proses pembuatan ecoprint lebih cepat; (2) Diperlukan adanya konsistensi dalam pemanfaatan media sosial seperti pengunggahan foto maupun video untuk menarik pelanggan; (3) Diperlukan adanya koordinasi antara dinas terkait dengan pemerintah lokal dalam menunjang keberlangsungan usaha Batik Dewandaru.

\section{DAFTAR PUSTAKA}

Alhusain, A. S. (2015). Kendala dan upaya pengembangan industri batik di Surakarta menuju standardisasi. Jurnal Ekonomi \& Kebijakan Publik, 6(2), 199-213. https://doi.org/10.22212/jekp.v6i2.348

Bourdieu, P. (2009). Pengantar Paling Komperehensif terhadap Pemikiran Bordiue. Terjemahan. Yogyakarta: Jalasutra.

Hoti, E. (2015). The technological, organizational and environmental framework of is innovation adaption in small and medium enterprises: Evidence from research over the last 10 years. International Journal of Business and Management, 3(4), 1-14. https://doi.org/10.20472/BM.2015.3.4.001

Kurniawati, D. W. (2017). Ungkapan estetis Batik Blora: Upaya eksplorasi nilai-nilai kebudayaan lokalitas dalam membangun identitas. Imajinasi: Jurnal Seni, 11(2), 126-134.

Kotler, P. (1991). Kotler on. Management Decision, 29(2). https://doi.org/10.1108/00251749110004961

Latief, N. D., \& Sayatman, S. (2019). Eksplorasi desain motif baru batik Kota Malang. Jurnal Sains dan Seni ITS, 8(2), F288-F293. https://doi.org/10.12962/j23373520.v8i2.49242 
Pengembangan Industri UMKM Batik Khas Kabupaten Malang melalui Digitalisasi Marketing Mix dan Teknologi Vika Annisa Qurrata, Ermita Yusida, Sudjatmiko Sudjatmiko, Lustina Fajar Prastiwi

Mandasari, D. J., Widodo, J., \& Djaja, S. (2019). Strategi pemasaran Usaha Mikro, Kecil dan Menengah (UMKM) Batik Magenda Tamanan Kabupaten Bondowoso. Jurnal Pendidikan Ekonomi: Jurnal Ilmiah Ilmu Pendidikan, Ilmu Ekonomi dan Ilmu Sosial, 13(1), 123-128.

https://doi.org/10.19184/jpe.v13i1.10432

Nugrayasa, O. (2014). Ketika produk impor membanjiri pasar Indonesia. Retrieved from: http://setkab.go.id/artikel-11655-.html. 12 September 2020.

Pradiani, T. (2017). Pengaruh sistem pemasaran digital terhadap peningkatan volume penjualan hasil industri rumahan. JIBEKA: Jurnal Ilmiah Bisnis dan Ekonomi Asia, 11(2), 46-53. https://doi.org/10.32812/jibeka.v11i2.45

Primadhyta, S. (2015). Menteri Gobel Bakal Larang Impor Batik. CNN Indonesia. Retrieved from: http:// www.cnnindonesia.com/ekonomi20150411153228-78-45910/menterigobel-bakal-larangimpor-batik/

Rahmiaji, L. R., Sulistyani, H., \& Raharjo, T. (2020). Promosi digital sebagai upaya penguatan manajemen pemasaran batik di Kampung Gedong Kota Semarang. Journal of Community Development \& Empowerment, 1(1), 41-52. https://doi.org/10.29303/jcommdev.v1i1.5

Saveria, R. A. (2016). Analisis digital marketing dalam strategi integrated marketing communication kampanye politik. Thesis. Universitas Indonesia Library.

Setyorini, C. T., \& Susilowati, D. (2019). Pendampingan UMKM Batik dalam mengoptimalkan nilai tambah UMKM melalui pelatihan pembuatan motif batik khas Purbalingga. Darma Sabha Cendekia, 1(1), 54-61. https://doi.org/10.20884/1.dsc.2019.1.1.2191

Ulliyawatik, U. (2018). Application of comprehensive budget preparation on UMKM Batik Malang (Study at UMKM Batik Blimbing- Malang). Manajemen Bisnis, 7(1), 1-9.

https://doi.org/10.22219/jmb.v7i1.6803

Ulum, I. (2009). Batik dan kontribusinya terhadap perekonomian nasional. Jurnal Bestari, 42, 21-32. 